\title{
The Modern Slaves: Specialized Knowledge and Democratic Governance
}

\author{
Nico Stehr • Jason L. Mast
}

Published online: 30 November 2010

(C) Springer Science+Business Media, LLC 2010

\begin{abstract}
This article examines widely held assumptions among scientific elites positing that there is an increasing discrepancy between those with specialized knowledge and laypersons, that governmental policy is increasingly shaped by scientific research and its practitioners, and that these trends pose a threat to representative democracy. This article asserts that modern liberal democratic societies are characterized by enabling structural changes that have expanded the forms of and means for citizen action, and simplified civil society's access to specialized knowledge.
\end{abstract}

Keywords Specialized knowledge Elites $\cdot$ Representative democracy

We begin our reflections about knowledge and democratic governance with a rather broad set of questions and claims: As Max Horkheimer emphasized - in contrast to Karl Marx-justice or equity and freedom do not mutually support each other. Does this also apply to democracy and knowledge? Or is knowledge a democratizer? Is the progress of knowledge, especially rapid advances of specialized knowledge, a burden on democracy, civil society, and the capacity of the individual to assert his or her will? If there is a contradiction between knowledge and democratic processes, is it a new development? Or is the advance of liberal democracies co-determined by the joint forces of knowledge and democratic political conduct, enabling one to claim that civil society, if not democracy, is the daughter of knowledge? Is it perhaps a naive faith in knowledge that propels such a conviction?

N. Stehr $\cdot$ J. L. Mast $(\bowtie)$

Karl Mannheim Chair for Cultural Studies, Zeppelin University,

Am Seemooser Horn 20,

88045 Friedrichshafen, Germany

e-mail: jason.mast@zeppelin-university.de
There are two hardly ever contested assertions about our age: Scientific expertise is a salient political resource, and most of the knowledge gained in the collective quest of knowledge is inaccessible to most living people. The growing gap between those who command specialized knowledge as well as those with political influence on the one hand, and most citizens who are in this respect disenfranchised on the other, is widely interpreted, along with the loss of sovereignty at the collective level through the globalization process, as a serious stress on nationbound representative democracy. In the case of knowledge production and knowledge use we are on an accelerating path away from what the influential member of the Vienna Circle, Otto Neurath, called for, namely a democratization of knowledge. However, as we will argue, the observations about the lack of democratic control of knowledge are not reason for premature despondency. Nor are these views necessarily unique to our age.

In an essay in the New York Review of Books in 2004, the molecular biologist Richard Lewontin maintains that "the knowledge required for political rationality, once available to the masses, is now in the possession of a specially educated elite, a situation that creates a series of tensions and contradictions in the operation of representative democracy." We do not want to engage Lewontin's excursion into what he describes as an obviously better, past history of society in which, as in early modern theories of democracy, every woman and man was just as competent as every other man and woman and knowledge therefore was available to the masses. Nor are we able to offer details about modern society in which the present would be like Lewontin's past. Instead, we will try to dispute his observations about contemporary society. Lewontin's disparaging views about the competence of the public are widely shared in the scientific as well as social scientific communities, as a recent inquiry of the Pew Center demonstrates. We will make 
reference to Michel Foucault as a pertinent case in point. Given the political conditions sketched, and under the conditions of the persistent evolution of science and technology, a simple question remains, are citizens still heard? Is there indeed a fundamental contradiction between system effectiveness and citizen participation in modern democracies?

We will tackle the issues in a number of steps. We begin by referencing some basic changes in modern society that play a role in these considerations. Second, we offer a brief definition of the core terms, and refer to the work of Foucault as an important perspective that supports the contention that knowledge tends to flow to the powerful and enhances their grip on power. Third, we advance the contention that knowledge as well as highly specialized knowledge can very well be a powerful weapon of the weak. We conclude with some observations about the linkages between knowledge and democratic governance that are not as demanding as the conventional, weary perspective on the decline of participatory democracy suggests.

\section{The Know Nothings}

Over the past decades, the case for the nature and the consequences of the sharp division, even schism, between experts and laypersons in many fields of human activity is virtually always conceived as a deficit for which those left behind - the ordinary actors - are responsible. In democratic societies therefore the "sphere" of authority increasingly encroaches on the "sphere" of liberty. What remains missing entirely are references to the responsibilities that come with the isolation of knowledge within either private or state serving communities of experts. Thus, the lack of an engagement of science with civil society or the creative possibilities of science to constitute a public sphere for science needs to become a topic. We will return to these issues in a moment. But first some further reflections of the gradient between science and democratic practices.

Although the distance of science to common sense knowledge is not a new phenomenon, it is widely assumed that the gradient of the separation between the commands of specialized scientific knowledge and everyday knowledge has radically increased in modern societies, and hence on the political plane a growing authority and power is assumed by "elite public policy specialists" (Robert Dahl) who are no longer intellectually, let alone democratically, accountable to many segments of the public.

The concerns expressed by prominent members of the contemporary scientific community about the precarious foundations for effective democratic participation of the vast majority of ordinary citizens in many ways echo and repeat earlier concerns, empirical findings, and vigorous discussions (e.g. the debates between Walter Lippmann (1992/1997) and John Dewey (1927), and the empirical studies of Hyman and Sheatsley (1947), Berelson et al. (1954), and Converse (1964)) about the feasibility of representative democracy and effectual citizen participation given the lack of civic competence or, more disparagingly, the political ignorance of many citizens of democratic states. More recently, the legal scholar Richard Posner suggested that the average citizen is "basically ignorant" about political affairs and that democracy should never aspire to be anything but a means of rotating elites. Survey research findings about the prevalent lack of political "knowledge" and gaps in political information among all social strata in modern societies are quite common; however, there is much less agreement about the origins, the significance, and the implications of these findings. Are such gaps stresses on the functioning of democratic regimes? Or is "public ignorance" perhaps even rational?

Summing up the state of discourse on these matters, the dominant conjecture among scientists is that scientific knowledge-lacking apparently the attributes of provisionalness, fragmentariness, malleability, ambivalence and fragility (in fact it is the very absence of these features that make it powerful) - ascents to become the core foundation for policy decisions and with it the ways we collectively organize our life world and cope with its problems. As the historian of science Gerald Holton notes with some despondency, "the new illiterates will be slaves with respect to key issues of self-governance".

The question the pessimistic narrative about the gradient between distributed modern knowledge and democracy also raises is: what nurtures these concerns and what are some of the family resemblances and elective affinities of this perspective with other influential views about the nature of modern society?

Our general claim would be, first of all, that a proper understanding of the issue of the links between democracy, knowledge, and the public should be embedded in a theory of modern society, one that accounts for how shifts in the characteristic distribution of power within and among major social institutions accompany significant structural changes in society more broadly. Concerns about the disenfranchisement of citizens in modern societies fail to consider a couple of important enabling structural changes typical of modern societies, namely the historically unprecedented prosperity supplanting salvation as the reason for human existence. The growth of the average cultural, social, and economic capital in many societies of the world since the end of WW II is unparalleled. However, an increase in cultural capital does not necessarily assure a convergence of scientific and non-scientific perspectives (for example, on climate change). Perhaps equally important are advances in 
science and technology that modify the foundation and enlarge the spaces for citizen action. These changes often translate into political action. But the ways in which citizen preferences, world-views, and moral values are translated into political practices do not necessarily occur in unmediated or expected avenues, for example, through a direct engagement in debates about the consequences of change induced by scientific or technological knowledge or through electoral participation.

In addition to the societal changes that are relevant, a correction to the prevailing written narrative of the gradient between specialized and ordinary forms of knowledge, dominated of course by scientists, science journalists, and a few interested laypersons, is in order. For example, does knowledge really inevitably end up in the hands of the powerful?

As we have emphasized, we are living in a historically unprecedented time if considered from a purely economic (capital) and educational (capital) point of view. In the developed world, affluence and educational levels in the sense of capabilities are by no means uniform and equally distributed, yet they are widespread and much more widespread than at any other time in history. The major post-war social transformations represented by these developments are relevant in the context of the relations between power and knowledge in as much as they are in the case of the basic changes in market relations or the foundations of knowledge politics.

\section{The Terms}

Knowledge may be defined as a capacity for action. Our use of the term "knowledge" as a capacity for action is derived from Francis Bacon's famous metaphor that knowledge is power (scientia est potentia). Bacon suggests that knowledge derives its utility from the capacity to set something in motion, represented in such modern examples as new communicative devices, new forms of power, new regulatory regimes, new chemical substances, new political organizations, new financial instruments, or the ability to diagnose new illnesses. To refer to but one concrete instance of knowledge as a capacity for action: In 1948, Claude Shannon published a small volume entitled The Mathematical Theory of Communication. In it he explained how words, sounds, and images could be converted into blips and sent electronically. Shannon foretold the digital revolution in communications.

Possession of knowledge, including knowledge about knowledge, enhances agency. However, the implicit if not manifest image of the public in the accounts about democracy and knowledge cited earlier refer to individuals who are not only incompetent but also politically ineffective.
It would be erroneous to underestimate a priori the ability of many segments of the public to mobilize knowledge in effort to challenge powerful social actors. Contrary to what one might surmise, political activity that challenges elite knowledge is by no means absent or declining in modern society.

As Ringen's contribution to this issue indicates, there are many definitions of democratic, and there is a large number of more or less rival hypotheses that refer to reasons for the emergence and persistence of democratic regimes. Democratic governance refers to extensive liberties for individual action including multiple loyalties as well as protecting such liberties from large institutions encroaching on individual beliefs and conduct.

\section{Knowledge as a Weapon of the "Weak"}

Speaking matter-of-factly about the distribution of competencies in modern society, Robert K. Merton noted that not all individuals are "equally competent to do the work of a democratic polity. They differ in capacity, in acquired skills, and in knowledge." Much more prominent theories of knowledge and power tend to assert a radical break and distance between those who command both power and knowledge. One of these well-known theories of knowledge and power is that proposed by Michel Foucault. His views converge, at least in its consequences with those of prominent scientists, in the sense that Foucault too depicts ordinary citizen as rather helpless victims of disciplinary knowledge.

We reject Foucault's microphysics of power theory. Foucault generally describes how knowledge produces us as subjects. With this we agree, in part. But as is well known, and where we depart from his thought, in his genealogical work, Foucault describes the individual as shaped by scientific disciplines in a one-sided way, where the individual's entire existence is controlled by institutions of subjugation such as penology and psychoanalysis, etc., and the enormous micromanaged power of regimentation and measurement embedded in major social institutions leaves the populace powerless to resist. In his essay on enlightenment, Foucault poses what for him is the central enlightenment dilemma: "How can the growth of capabilities be disconnected from the intensification of power relations?"

Foucault's observations on "the undoing of the subject" and the subject as a passive victim are based on a view that assigns too much power to the agencies that deploy knowledge, and one that neglects the possibility that the knowledge of large institutions such as the state may have benign sides and moral purposes. Knowledge, as described in Foucault's The Archaeology of Knowledge, is an anonymous discourse that exercises control over unwitting and powerless individuals. Foucault thereby 
underestimates the malleability of knowledge, the uncertainties associated with knowledge, the extent to which knowledge is contested, and the capacity of individuals and civil society organizations to appropriate and mobilize knowledge in order to evade, disrupt, oppose, and restrain the oppression or the power that may be exercised by major social institutions in modern society. The ability to evade, disrupt, oppose, and restrain power refers, for example, to everyday forms of resistance. The unorganized withdrawal of compliance and unstructured abandonment of trust represent manifestations of resistance based on the knowledgeability of the allegedly weak that is frequently overlooked in favor of more spectacular but less frequent forms of open rebellion. It is important to recognize and examine knowledge as a source of power of the helpless, as a source of agency that enables and facilitates elitechallenging political activities. The Internet, for instance, enhances the mobilization of knowledge among the weak.

Of course, there are-aside from knowledge specific attributes such as its distance to ordinary discourse - various societal restraints and institutional arrangements such as the ownership of knowledge through patents and copyright that affect the wide dissemination and utilization of knowledge in society and thus hinder the effective role that knowledge could play in a democracy.

\section{The Fate of Knowledge Claims}

The philosopher of the French Enlightenment, the Marquis de Condorcet, was convinced that "the argument that the citizen could not take part in the whole discussion and that each individual's argument could not be heard by everyone can have no force." For Condorcet the issue was not one of competency with respect to the issue at hand but of good rules and settings within which individuals would be able to deliberate jointly. Aside from the normative or even constitutional empowerment of ordinary citizens to be heard on policy matters, even if it involves highly specialized knowledge claims, Condorcet reminds us that collective deliberation and involvement benefits from rules, settings, and opportunities conducive to such reflection. One of the persistent and foremost challenges of democratic governance is to generate and maintain motivation among its citizens to become and remain knowledgeable. In sum, public engagement and participation in science is not hazardous for the scientific community; it is part of the social architecture of democracy. But this is one side of the issue of the relation of democracy and specialized knowledge.

The other side of the coin pertains to assertions that the public consideration of specialized knowledge claims is a futile enterprise from the beginning because of the inability of ordinary citizens to engage in public deliberation of such forms of knowledge. This argument essentially enshrines instrumental rationality as the mode governing the linkage between scientific knowledge - understood of course to have those distinctive merits that enable calculational decision-making - and society, allowing for policy decisions to become more and more efficient.

The basic claim of our observations for the moment is that the evolvement of modern societies as knowledge societies increasingly extends to the democratization and negotiation of knowledge claims. We are slowly moving from what has been the case of expert rule to a much broader, shared form of knowledge claims governance. After all, it is one of the virtues of (liberal) democracies that citizens are to be involved in political decisions. Such participation, whatever formal basis it may assume, does not hinge, as a prerequisite, on the degree of technical or intellectual competence citizens may command.

In addition, we make the assumption that scientific and technical knowledge are not only more malleable, and accessible, and definitive, in practice than has been suggested in the classical perspective, such as the "enlightenment model," of the relations between science and society. Rather, the new sociology of scientific knowledge has demonstrated that the production of scientific knowledge is in many ways very similar to other social practices, and that the wall between science and society is lower than frequently assumed even while it has by no means disappeared.

In short, the boundaries between expertise and everyday knowledge are much less fixed and more robust than has often been surmised, especially in those observations cited that lament the growing distance between expert knowledge and the public's knowledge.

Moreover, what counts increasingly as problematic in modern society is not that we may now know enough but that we may know too much. Societal negotiation of novel capacities for knowledge (generated in science and in technology) is not as dependent on specialized natural scientific and technical knowledge as on the enabling knowledge generated by the social sciences and the humanities.

General access of civil society to enabling knowledge produced in the social sciences faces fewer hurdles than in the natural sciences. Knowledgeability has gained social externality through production of a more participatory democracy or citizenship, which benefits civil society organizations the most. All of this produces particular challenges not only in terms of access to social science knowledge but also in the form of new modes of participation. It is here that civil society organizations will be challenged.

Social space for communication between science/ social science and the public already exists. The 
possibility for democratic negotiation and scientific practice has to be seen as part of a larger social enterprise and a larger social context in which both professional scientists as experts and the lay public engage in discourse. Science is an effective social force because it can engage and rely in turn on civil society organizations and institutions. And, as Otto Neurath stressed in the last paper he published: "I do not think that one can distinguish between the problems of the scientists and the problems of the man in the street. In the end, they are more interlinked than people sometimes realize. Any synthesis of our intellectual life, any orchestration of various attempts to handle life and arguments should never forget these far reaching social implications."

Finally, we should not be too harsh about the lack of scientific foundation in much of what we treat as knowledge in ordinary life because we tend to get on quite well with such knowledge, at least most of the time and for most practical purposes at hand; and as Ludwig Wittgenstein notes, "my life consists in my being content to accept many things".

And when it comes to the knowledge necessary to judge politics, John Stuart Mills' pragmatic observation would seem to be still valid:

[a] person must have a very unusual taste for intellectual exercise in and of itself, who will put himself to the trouble of thought when it is to have no outward effect. . . The only sufficient incitement to mental exertion, in any but a few minds in a generation, is the prospect of some practical use to be made of its results.

Finally, in a world of rapidly changing, specialized cognitive skills, those who complain about the lack of knowledge among large segments of society are often those left behind in their command of the new forms of knowledge leading to intriguing conflicts of authority, power, age and knowledge.

\section{Further Reading}

Berelson, B., Lazarsfeld, P. F., \& McPhee, W. N. 1954. Voting: A study of opinion formation in a presidential campaign. Chicago: University of Chicago Press.

Bohman, J. 1999. Citizenship and norms of publicity. Wide public reason in cosmopolitan societies. Political Theory, 27, 176-202.

Carolan, M. S. 2006. Science, expertise, and the democratization of the decision making process. Society and Natural Resources, 19, 661-668.

Converse, P. E. 1964. The nature of belief systems in mass publics. In D. E. Apter (Ed.), Ideology and discontent (pp. 206-261). New York: Free Press of Glencoe.

Dahl, R. A. 1992. The problem of civic competence. Journal of Democracy, 3, 45-59.

Dewey, J. 1927. The public and its problems. New York: H. Holt and Co.

Fischer, F. 2009. Democracy and expertise: Reorienting public inquiry. Oxford: Oxford University Press.

Holton, G. 1986. The advancement of science, and its burdens. Daedalus, 115(75), 77-104.

Hyman, H. H., \& Sheatsley, P. B. 1947. Some reasons why information campaigns fail. Public Opinion Quarterly, 11, 412423.

Lippmann, W. 1992/1997. Public Opinion. New York: Free Press.

Rosanvallon, P. 2006. Democracy: Past and future. New York: Columbia University Press.

Stehr, N. 2005. Knowledge politics: Governing the consequences of science and technology. Boulder: Paradigm Publishers.

Nico Stehr is Karl Mannheim Professor for Cultural Studies at Zeppelin University/Lake Constance/Germany. He has recently published (jointly with the climate scientist Hans von Storch) Climate and Society. His inquiry into the societal role of expertise (with Reiner Grundmann) will be published by Routledge.

Jason L. Mast is Assistant Professor of Cultural Studies at Zeppelin University/Lake Constance/Germany. He received his $\mathrm{PhD}$ in Sociology from UCLA. His forthcoming book is entitled Power and Performance: The Clinton Years. 